\title{
Islam in the Indonesian religious soap opera: faithfulness for the sake of commodification
}

\author{
Muzayin Nazaruddin ${ }^{1, *}$ \\ ${ }^{1}$ Universitas Islam Indonesia, Communications Department, J1. Kaliurang 14.5 Sleman, Yogyakarta, \\ Indonesia
}

\begin{abstract}
This study discusses Islam representation in Indonesia, focusing on the adaptation of Islamic-mystic magazines into religious soap operas. Its aim is to reveal the norms underlying the adaptation processes. It analyses Hidayah magazine, one of the most popular Islamic-mystic magazine in Indonesia, as the source text, and Rahasia Ilahi, the highestrating religious soap opera, as the target text. The study finds that the basic norm underlying the adaptation processes is market orientation. It determines two subsequent norms, namely the narrative standardization and faithfulness. The flexible narrative sequence in the magazine should be standardized into the fixed cause-effect narrative structure of soap opera. It creates a more specific norm, namely extreme binary opposition. Meanwhile, faithful norm has three aspects, namely adequacy, factual, and Islamic teaching conformity principles. This three-aspects of faithfulness is specific feature of the religious texts translation.
\end{abstract}

\section{Introduction}

Within the Indonesian society, in which religion, especially Islam, plays important roles in the socio-cultural dynamics, the representation of Islam in almost all types of mass media is everyday phenomena and has a long history.

This paper focuses on one recent phenomenon of Islam representation in Indonesia, namely the adaptation of Islamic-mystic magazines into religious soap operas. The aim of the study is to reveal the norms underlying the adaptation processes. The study analyses Hidayah magazine, one of the most popular Islamic-mystic magazine in Indonesia, as the source text, and Rahasia Ilahi (The Secret of God), the highest-rating religious soap opera, as the target text. Thus, the research questions of the study are: what kind of norms underlie the adaptation processes from Hidayah magazine into Rahasia Ilahi? How these norms work in such processes of adaptation?

\section{Research method}

The research is done through two stages. First, I conducted some general analysis dealing with the huge number of religious soap operas and Islamic-mystic magazines. This step was hand in hand with my daily activities as audience who had routinely watched and read them,

*Corresponding author: muzayin.nazaruddin@uii.ac.id, begawan.nazaruddin@gmail.com 
since 2002 to 2006. Second, I specifically analysed nine editions of Hidayah magazine, randomly chosen from 2003 to 2006: Hidayah 28, November 2003; Hidayah 33, April 2004; Hidayah 45, April 2005; Hidayah 46, May 2005; Hidayah 49, August 2005; Hidayah 53, December 2005; Hidayah 54, January 2006; Hidayah 58, May 2006; and Hidayah 59, June 2006. In these nine editions, there were 41 mystical stories in 'Iktibar' (The Real Experience) column, which always become the source text of the adaptation into religious soap operas. Besides, I also analysed 18 episodes of Rahasia Ilahi, an adaptation of Iktibar column in Hidayah magazine.

In this study, I follow the analysis model proposed by Cattrysse [2], consist of four steps: the selection policy of the source texts, the adaptation policy of the texts that have been selected, the function of the target text within its contexts, and the relations between selection-adaptation policies and the function of the target text within its context. But, due to the limited pages, this paper would only discuss the first and second steps. This model is chosen because of the similarity of the object study that includes large amounts of texts, not just a single-pairs text (from one source text to one target text), and the similarity of the study aim, that is revealing the norms behind the adaptation. Cattrysse has analysed American noir films made from 1940 to 1960 . In this study, I analyse the religious soap operas aired from 2004 to 2007.

\section{Selection policy}

Religious soap opera first emerged in 2004. A year later, in May 2005, according to AC Nielsen survey, there were 35 titles of them [9]. Even, I found at least 44 titles of religious soap operas in all Indonesian television during 2004 to 2007 [16]. Of course, not all of them are the adaptation of certain source texts. Then, how many of them are the adaptation and how many are not, or purely based on the screenplay? The lack of adequate documentation of television programs in Indonesia makes a considerable difficulty to answer this question quantitatively. However, I found that some of them mentioned clearly the source text of their stories (Table 1).

Table 1. Religious soap opera and its source text

\begin{tabular}{|l|l|l|l|}
\hline No & Religious soap opera & Television & \multicolumn{1}{|c|}{ Source text } \\
\hline 1. & $\begin{array}{l}\text { Rahasia Ilahi (The God } \\
\text { Secret) }\end{array}$ & TPI & Hidayah magazine \\
\hline 2. & $\begin{array}{l}\text { Takdir Ilahi (The God } \\
\text { Destiny) }\end{array}$ & TPI & $\begin{array}{l}\text { Hadith of Prophet Muhammad in the } \text { Bukhari } \\
\text { Muslim book }\end{array}$ \\
\hline 3. & Astaghfirullah & SCTV & Ghoib magazine \\
\hline 4. & Iman (The Faith) & SCTV & Hidayah magazine \\
\hline 5. & Taubat (The Repentance) & TransTV & Insting magazine \\
\hline 6. & Hidayah (The Guidance) & TransTV & Hidayah magazine \\
\hline
\end{tabular}

Source: main data (collected, compiled and arranged by the researcher)

We may notice from the table that there are three magazines become the source texts, i.e. Hidayah, Ghoib, and Insting. These three magazines belong to the same genre, that is Islamic-mystic magazine. According to Irawanto [7], this genre is a new phenomenon emerged after the Indonesian political reform in 1998. The genre was pioneered by Hidayah magazine in 2001. Since the first edition, this magazine immediately gained success, sold 10,000 copies, and constantly raised their printed copies every year. In 2004, according to AC Nielsen survey, Hidayah magazine becomes the most widely read magazine in Indonesia [12]. Then, this success created a new trend, marked by the emergence of the epigones, such as Hikayah, Ghoib, Insting, Alkisah, Kisah Nyata, Posmo, and others. They 
have common identity signifier, i.e. having specific column for mystical or irrational stories, interpreted with Islamic teachings, generally as the evidence of God's power.

Obviously, this market success initially drives the emergence of religious soap opera. Having a great success, more than ten production houses offered cooperation with Hidayah magazine in terms of adapting and broadcasting its mystical stories into television program [13]. In 2004, Kusuma Eka Perkasa (KEP), a production house in Indonesia, produced Rahasia Ilahi (The God Secret) as an adaptation of mystical stories in Hidayah magazine, and broadcasted it on TPI (Televisi Pendidikan Indonesia, now known as MNC TV), one of Indonesian national televisions. This first religious soap opera in Indonesia gained a great success. Then, TPI launched the second religious soap opera, titled as Takdir Ilahi (The God Destiny). It has reached the top-ten rating of Indonesian television programs only in two months after its launching. According to AC Nielsen survey, during March and April 2005, Rahasia Ilahi got 14.9 rating score and 40.29\% share score, it was on the top of the 50 programs in all Indonesian televisions. Besides, Takdir Ilahi was in the third place with 9.8 rating score and $22.8 \%$ share score. The success of these two religious soap operas had placed TPI as the highest rating television at that period [19, 22].

Motivated by this success story, almost all Indonesian televisions produced similar soap opera, in which the mystical or irrational stories and Islamic symbols become the distinctive identity. Then, this genre rapidly grew from 2005 to 2007; some of them were very popular and reached 10 highest-rating television programs $[19,4,8]$. Thus, regarding its history, the rating or market orientation seems to be the basic motivation of the adaptation of Islamicmystic magazines into religious soap operas. Hence, the media looks at religion, especially Islam, as a marketable commodity. It also means, this is not a matter of Islamic propagation. This conclusion may lead to the thesis of "marketization or commodification of Islam" that has pointed out by many Indonesian experts, such as Sasono [17], Masduki [14], or Setiawan [18].

\section{Adaptation policy}

In the adaptation policy level, there are several points should be analysed. The most fundamental one is the shift in the genre, from the factual genre towards the fictional one. Hidayah magazine claims that their story is not just a fiction. It is news that is packaged in a feature style, and is written based on the report conducted by their journalists. Another Islamic-mystic magazines followed this factual claim; most of them claim that the stories presented are real experiences. The factual claim is supported by the presence of informants or witnesses. In addition, the witnesses statements are often written separately from the main text, in special additional columns, in order to emphasize its importance.

Actually, many columns in Hidayah magazine which are claimed as journalistic reports were full of writer's interpretations. There was no clear differentiation between facts and opinions. This is actually a proof of the general phenomena of the journalism weakness within Islamic media in Indonesia, as has been shown by Muhammad [15] and Irawanto [7]. But, in general, though very interpretive, Iktibar column in Hidayah magazine could still be classified as a journalistic report.

However, in the adaptation level, the model chosen is soap opera, which is generally considered as fictional genre, not factual. Eventhough, religious soap operas also make similar factual claim. In the opening shot of Rahasia Ilahi, we will find a big note on the television screen: "This is a real story taken from Hidayah Magazine - name and character have been changed". Some other religious soap operas also claim that their stories are fact, gathered from various sources (see Table 1).

The problem also lies on the change of production mode, from magazine (print media) to soap opera (electronic media). Change in the production mode is complex in terms of 
interpretation and translation, so it always produces new meaning. In this case, the producer interprets and translates the content of magazine into visual and aural format of television show, and ultimately blur the boundary between fact and fiction. It has important consequences to the narrative structure of the text. My observation on Iktibar column finds five types of narrative structure, namely the story of su'ul khotimah (bad death), the story of khusnul khotimah (good death), the story of repentance, the story of God's punishment, and the story of God's mercy. Likewise, my observation on religious soap operas, especially Rahasia Ilahi, also finds those five stories. Each story has different narrative structure, but has some fundamental similarities. Table 2 describes in detail these five types of narratives.

Table 2. Five types of narrative structures

\begin{tabular}{|c|c|c|}
\hline \multirow[t]{2}{*}{ Narrative type and elements } & \multicolumn{2}{|c|}{ Comparison } \\
\hline & Hidayah Magazine & Rahasia Ilahi \\
\hline \multirow{3}{*}{$\begin{array}{l}\text { The story of su'ul khatimah, } \\
\text { generally tells the tragic death. } \\
\text { a. Depiction of tragic death of } \\
\text { the main character. } \\
\text { b. Description of bad } \\
\text { behaviour of the main } \\
\text { character during his/her } \\
\text { lifetime as the cause of } \\
\text { tragic death. } \\
\text { c. Reflection on the story } \\
\text { presented, usually by citing } \\
\text { the Quran or hadith. }\end{array}$} & $\begin{array}{l}\text { No definite narrative } \\
\text { sequence. However, the } \\
\text { most used sequence: } \\
\text { reflection (lead), tragic } \\
\text { death, bad behaviour, and } \\
\text { reflection. }\end{array}$ & $\begin{array}{l}\text { A fixed narrative sequence: } \\
\text { opening reflection, bad } \\
\text { behaviour, tragic death, and } \\
\text { closing reflection. }\end{array}$ \\
\hline & $\begin{array}{l}\text { The story of tragic death and } \\
\text { bad behaviour are the main } \\
\text { narrative portions, longer } \\
\text { than the reflection. }\end{array}$ & $\begin{array}{l}\text { The description of bad } \\
\text { behaviour becomes the largest } \\
\text { narrative portion. }\end{array}$ \\
\hline & $\begin{array}{l}\text { Informant testimonies in the } \\
\text { text, especially in some } \\
\text { separate additional columns. }\end{array}$ & No informant testimony. \\
\hline \multirow{3}{*}{$\begin{array}{l}\text { The story of khusnul khatimah, } \\
\text { generally tells the wonderful } \\
\text { and memorable death. } \\
\text { a. Description of beautiful } \\
\text { death of the main character. } \\
\text { b. Description of good } \\
\text { behaviour as the cause of } \\
\text { beautiful death. } \\
\text { c. Reflection. }\end{array}$} & $\begin{array}{l}\text { The most used narrative } \\
\text { sequence: reflection (lead), } \\
\text { beautiful death, good } \\
\text { behaviour, and reflection. }\end{array}$ & $\begin{array}{l}\text { A fixed narrative sequence: } \\
\text { opening reflection, good } \\
\text { behaviour, beautiful death, and } \\
\text { closing reflection. }\end{array}$ \\
\hline & $\begin{array}{l}\text { The story of beautiful death } \\
\text { and good behaviour are the } \\
\text { main narrative portions. }\end{array}$ & $\begin{array}{l}\text { The description of good } \\
\text { behaviour becomes the largest } \\
\text { narrative portion. }\end{array}$ \\
\hline & Informant testimonies. & No informant testimony. \\
\hline \multirow{3}{*}{$\begin{array}{l}\text { The story of repentance, tells the } \\
\text { repentance event. } \\
\text { a. Description of bad } \\
\text { behaviour of the main } \\
\text { character before repentance. } \\
\text { b. Description of the } \\
\text { repentance processes. } \\
\text { c. Reflection. }\end{array}$} & $\begin{array}{l}\text { The most used narrative } \\
\text { sequence: reflection (lead), } \\
\text { bad behaviour, repentance } \\
\text { processes, and reflection. }\end{array}$ & $\begin{array}{l}\text { A fixed narrative sequence: } \\
\text { opening reflection, bad } \\
\text { behaviour, repentance event, } \\
\text { and closing reflection. }\end{array}$ \\
\hline & $\begin{array}{l}\text { The description of } \\
\text { repentance processes and } \\
\text { bad behaviour are the main } \\
\text { narrative portions. }\end{array}$ & $\begin{array}{l}\text { The depiction of bad behaviour } \\
\text { becomes the largest narrative } \\
\text { portion. The repentance event } \\
\text { only depicted shortly in the end. }\end{array}$ \\
\hline & Informant testimonies. & No informant testimony. \\
\hline \multirow{3}{*}{$\begin{array}{l}\text { The story of azab, tells the } \\
\text { punishment from God. } \\
\text { a. Description of bad } \\
\text { behaviour of the main } \\
\text { character. } \\
\text { b. Description of the God's } \\
\text { punishment for the bad } \\
\text { behaviour. } \\
\text { c. Reflection. }\end{array}$} & $\begin{array}{l}\text { The most used narrative } \\
\text { sequence: reflection (lead), } \\
\text { bad behaviour, God's } \\
\text { punishment, and reflection. }\end{array}$ & $\begin{array}{l}\text { A fixed narrative sequence: } \\
\text { opening reflection, bad } \\
\text { behaviour, God's punishment, } \\
\text { and closing reflection. }\end{array}$ \\
\hline & $\begin{array}{l}\text { The description of God's } \\
\text { punishment and bad } \\
\text { behaviour have same } \\
\text { narrative portion, longer } \\
\text { than reflection. }\end{array}$ & $\begin{array}{l}\text { The description of bad } \\
\text { behaviour becomes the largest } \\
\text { narrative portion. The } \\
\text { punishment from God only } \\
\text { depicted shortly. }\end{array}$ \\
\hline & Informant testimonies. & No informant testimony. \\
\hline
\end{tabular}




\begin{tabular}{|c|c|c|}
\hline \multirow{3}{*}{$\begin{array}{l}\text { The story of God's mercy, tells } \\
\text { the beautiful and bizarre events } \\
\text { as evidence of God's love. } \\
\text { a. Description of the good } \\
\text { behaviour of the main } \\
\text { character. } \\
\text { b. Description of bizarre } \\
\text { events. } \\
\text { c. Reflection. }\end{array}$} & $\begin{array}{l}\text { The most used narrative } \\
\text { sequence: reflection (lead), } \\
\text { good behaviour, God's } \\
\text { mercy, and reflection. }\end{array}$ & $\begin{array}{l}\text { A fixed narrative sequence: } \\
\text { opening reflection, good } \\
\text { behaviour, bizarre event, and } \\
\text { closing reflection. }\end{array}$ \\
\hline & $\begin{array}{l}\text { The description of God's } \\
\text { mercy and good behaviour } \\
\text { have same narrative portion, } \\
\text { longer than the reflection. }\end{array}$ & $\begin{array}{l}\text { The depiction of good behavid } \\
\text { is the largest narrative portion } \\
\text { The bizarre event depicted } \\
\text { shortly in the end. }\end{array}$ \\
\hline & Informant testimonies. & \\
\hline
\end{tabular}

Source: main data (collected, compiled and arranged by the researcher)

We may see that there are fundamental similarities between the narrative structures of Rahasia Ilahi and Hidayah magazine. Nevertheless, there are also some differences between them indicating important changes in the adaptation processes. First, there is a standardization of narrative structure in the adaptation process. In Hidayah magazine, the stories do have constant narrative parts, but the order of the parts is flexible. Meanwhile, in Rahasia Ilahi the narrative sequence is standardized with the pattern of cause-effect: started with the causes and ended with the effects. Considering the production aspect of religious soap opera, the standardization of the narrative structure is understandable since its processes is much more complex than the production processes of printed magazine. Moreover, since the production intensity is very high, one episode in a week on average, the standardization of the narrative structure therefore is a needed strategy.

The other dimension of adaptation policy should be analysed is the difference between the character patterns of the source and target text. In Hidayah magazine, the story usually focuses on the main character; while other characters, such as families, friends or neighbours usually appear as witnesses or informants who talk about mystical event experienced by the main character. Secondary characters exist, but their role is very limited. In Rahasia Ilahi, secondary characters are usually more prominent. In fact, Rahasia Ilahi often adds other characters that do not exist in the source text. According to Greimas's actantial model [6], the most important additional character is the opponent. It creates an extreme binary opposition between the main character and the opponent. If the main character is a bad person, the opponent will be a very good person, who always persecuted by the main character. Conversely, if the main character is a very kind person, the opponent will be a very cruel person, who always disturbs the main character. Hence, there is an extreme binary opposition: extreme-good person and extreme-bad person. It already exists implicitly in the magazines, but it presents explicitly in a very strong way in the religious soap operas. It confirms Lotman's idea that the binary opposition principle is the basis for every literature text and work of art, and even for every sphere of human life [11].

The change in the narrative portions also strengthened such binary opposition. In Hidayah magazine, description of the causes and effects are generally in equal quantity; while in Rahasia Ilahi, description of cause dominates the show. For example, in the story of su'ul khotimah (bad death) and azab (punishment from God), the overall duration of the soap opera is dominated with the depictions of bad behaviour of main character. Instead, in the khusnul khotimah (good death) and God's mercy stories, the show is filled with the depictions of good behaviour of main character.

Religious soap operas effectuate an over exaggerated of generalization that the bad person will forever be bad, otherwise the good individual will forever behave good actions. The processes of changes, to be good from bad condition, or otherwise, or to be more mature, never shown. In the repentance story, it is more obvious. Typically, from the beginning to the middle scenes, the show is dominated by many bad behaviours of the main character, just to show that he or she is a sinner. Then, in the end of the show, suddenly the 
main character repents. The struggle and contemplation for repentance is not shown at all. Repentance is depicted as something happen suddenly and easily.

Besides the addition of the opponent, Rahasia Ilahi usually adds Islamic cleric (ustad or kyai) character as the helper. I find at least four representation types of ustad's roles: praying for the dead man being punished by God; fighting against the demon or witch; giving advise someone who has just converted; and preventing people who will do anarchists against the criminal. This representation is an excessive reduction. Various studies have demonstrated strong evidences of kyai's roles; especially through their pesantren (Islamic boarding school), in the development of education, economic empowerment, preservation of local literature and culture, as well as development of democratization $[1,3,5,21,25]$. These various roles do not exist in religious soap operas. They reduce the role of kyai in such a way: only in the 'mystical' and 'superstition' world. One of the very common closing scene in the religious soap opera is the fight between kyai and shaman, represented as the fight between 'goodness' and 'wickedness' [26]. It produces another binary opposition, between kyai as 'extreme angel' versus shaman as 'extreme evil'.

The last important dimension is the adaptation of 'the reflection' as a part of the narrative structure. In Hidayah magazine, the reflection is written by the journalist, as integral part of the story, in the beginning as the lead, and then reaffirmed in the end of the story. The same pattern is adapted in Rahasia Ilahi, there are opening and closing reflection. But, in Rahasia Ilahi, the reflections are actually not included as part of the soap opera itself, but done by Arifin Ilham, a young ustad who is very famous in Indonesia. Arifin Ilham is featured not to be an actor in the soap opera, but to open and to close the religious soap opera with Islamic teachings. He always appears in the opening and closing, quotes the verses of Quran or the hadiths of Prophet Muhammad, and dress as an ustad. It suggest that Arifin Ilham is giving an Islamic sermon, yet the medium is television, not mosque or Islamic school. Thus, it confirms Sisley [20] who has emphasized the notion of faithfulness in the translation of written bible to audio-visual media. The complexity of the translation, from one medium to another, is not merely about producing the new meaning, but also the problem of 'expected reception' when the producer expect the audience to belief in their products.

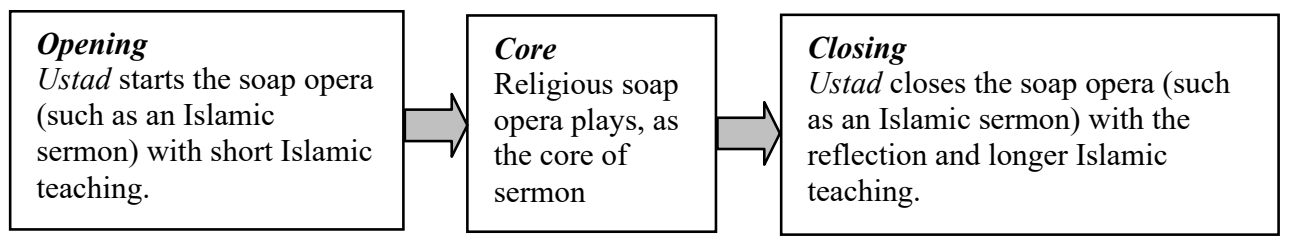

Fig. 1. The Islamic sermon as the narrative pattern of religious soap opera

The similar strategy, presenting popular kyai or ustad to give Islamic teaching, is also performed by another religious soap operas, as shown in Table 3.

Table 3. Popular ustad in the religious soap opera

\begin{tabular}{|l|l|c|l|}
\hline No & \multicolumn{1}{|c|}{ Soap Opera } & Television & \multicolumn{1}{|c|}{ Indonesian popular ustad } \\
\hline 1. & Rahasia Ilahi & TPI & Arifin Ilham \\
\hline 2. & Takdir Ilahi & TPI & Ali Mustafa Yaqub \\
\hline 3. & Astaghfirullah & SCTV & Jefri al Buchory \& Yusuf Mansur \\
\hline 4. & Kuasa Ilahi & SCTV & Jefri al Buchory \\
\hline 5. & Pintu Hidayah & RCTI & Luthfiah Sungkar \\
\hline
\end{tabular}

Source: main data (collected, compiled and arranged by the researcher) 
Carefully observing this norm, we will find slightly different notion of the faithfulness with common understanding in the translation studies, which usually understood as 'correct' translation of source text. In the correct translation, the principle of adequacy or equivalence between the adaptation and its original determines the quality of translation [2, $23,10]$. In the case of religious soap opera, the adequacy principle also seems important, by which they tend to state clearly the source text and prefer to follow the narrative structure of the source [24]. However, in the religious soap opera there are another more important dimensions of this faithfulness, i.e. the conformity with the teachings of Islam, based on a true story, or combination of both. Hence, there are some aspects of the faithful norm: adequacy, factual, and Islamic teaching conformity principles. I suppose this double meaning of faithfulness, refers both to the truthfulness adaptation of the source, and the religious teaching and real experience conformity, is the specific feature of the translation of religious text.

\section{Conclusion}

This study finds that there are some norms underlying the adaptation of Islamic-mystic magazines into religious soap operas, which are related to one another in certain hierarchical relation. Figure 1 illustrates the hierarchical relationship of these norms.

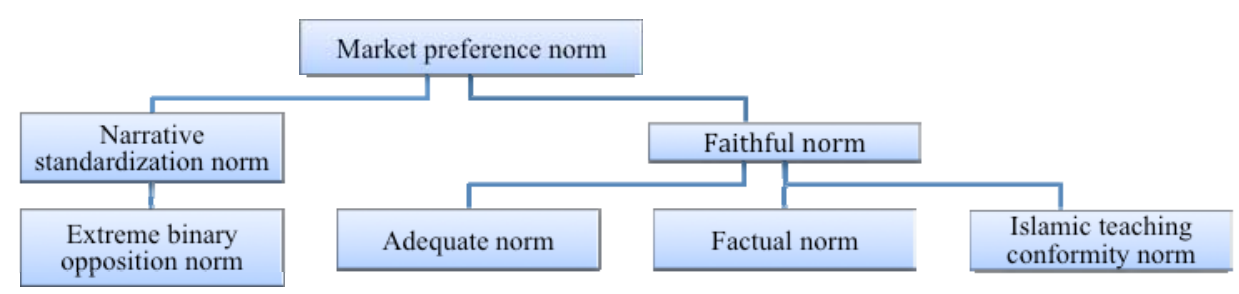

Fig. 2. The norms of the adaptation processes

The most fundamental norm is the popularity or market preference, determining the choice of adaptation from popular Islamic-mystic magazines, into soap operas that are also extremely popular. Thus, it is not a matter of Islamic propagation, but commodification of Islam. This economic motivation determines two subsequent norms, i.e. the narrative standardization and faithfulness. The flexible narrative sequence in the magazine should be standardized into fixed cause-effect narrative structure of soap opera. It creates a more specific norm, namely extreme binary opposition, which are already exist in the source text but amplified in the target text. Meanwhile, faithful norm has three aspects, namely adequacy, factual, and Islamic teaching conformity principles. This three-aspects of faithfulness is specific feature of the translation of religious texts. It is obvious in the explicit signifier in the religious soap operas mentioning the story as a real experience, also in the appearance of popular ustad to open and close the soap opera with Islamic teachings.

\section{Acknowledgements}

This article is part of the author's study at the Master Programme of Semiotics, University of Tartu, Estonia, sponsored by Directorate General of Higher Education (DGHE), Ministry of National Education, Indonesia. The author is very grateful to Elin Sütiste (Department of Semiotics, University of Tartu) for insightful comments on the draft of this article. 


\section{References}

1. L. Binder, Islamic tradition and politics: the kyai and the alim, Compr. S. in Soc. and Hist. 2 (1959).

2. P. Cattrysse, Film (adaptation) as translation: some methodological proposals, Target, 4.1, 53-70 (1992).

3. Z. Dhofier, The pesantren tradition: a study of the role of the kyai in the maintenance of the traditional ideology of Islam in Java (ANU, Canberra, 1980).

4. Fathuri, et al., Menjual kuburan di layar kaca, Majalah Syirah, July (2015).

5. C. Geertz, The javanese kyai: the changing role of a cultural broker, Compr. S. in Soc. and Hist. 2 (1959).

6. A.J. Greimas, Structural semantics (Lincoln \& London, Univ. of Nebraska Press, 1983).

7. B. Irawanto, Transformasi pers Islam di era reformasi, J. I. Sos. dan I. Pol. 9.3, 297-315 (2006).

8. S. Ivvaty, Tahun horor di republik hantu, Kompas, 30 December (2007).

9. A. Khudori \& A.R. Pitakasari, Sinetron keagamaan melorot setelah banjir, Gatra, 13 June (2005).

10. J. Lambert \& C. Robyns, Translation, In R. Posner, K. Robering, T.A. Sebeok (eds.), Semiotics: a handbook of nature and culture (Berlin \& New York, Walter de Gruiter, 2004).

11. Y.M. Lotman, Notes on the structure of a literary text, Semiotica, 15.3, 199-205 (1975).

12. Majalah Hidayah, Hidayah: empat tahun menorehkan sejarah, 49, August, 98-99 (2005).

13. Majalah Hidayah, Menengok perjalanan Majalah Hidayah di layar kaca, 49, August, 106-107 (2005).

14. Masduki, Religiotainment di era "budaya pop” televisi, J. IPTEK-KOM, 8.2 (2006).

15. A. Muhammad, Jihad lewat tulisan: kisah sukses Majalah Sabili dengan beragam ironi, J. Pantau, 2, 15 (2001).

16. M. Nazaruddin, Sinetron religius: sinetron islami?, J. Kom. 2.2, 315-330 (2008).

17. E. Sasono, Religiusitas layar kaca, Tempo, 3-9 October (2005).

18. I. Setiawan, Komodifikasi dan representasi nilai-nilai keislaman dalam tayangan televisi, J. IPTEK-KOM, 9.1 (2007).

19. Sinar Harapan, TPI melanjutkan perjuangan untuk tetap di atas, 8 April (2005).

20. J. Sisley, Translating from one medium to another: explorations in the referential power of translation (Univ. of Warwick, 2000).

21. K.A. Steenbrink, Pesantren, madrasah, sekolah (Jakarta, LP3ES, 1974).

22. Suara Merdeka, TPI andalkan sinetron religius, 22 February (2005).

23. P. Torop, Intersemiosis and intersemiotic translation, Eur. J. for Semiotic S., New Tartu Semiotics, 12.1 (2000).

24. G. Toury, A cultural-semiotic perspective, In T.A. Sebeok (ed.), Encyclopedic dictionary of semiotics (Berlin \& New York, Mouton de Gruyter, 1994).

25. E. Turmudi, Religion and politics: a study on political attitudes of devout muslims and the role of the kiai in contemporary Java, Southeast Asian J. of Soc. Sci. 23.2, 18-41 (1995).

26. K. Van Heeren, Cruelty, ghosts, and verses of love, ISIM Review 22, Autumn, 20-21 (2008). 